\title{
Mutations of DNA Repair Associated Gene, APEX in Human Colorectal Cancer
}

\author{
Sang-Hwan Oh, ${ }^{1,3}$ Hee-Boong Park ${ }^{2}$ and \\ Yu-Jin Kim \\ 1 Department of Biochemistry and Molecular Biology, \\ Yonsei University-College of Medicine, 134 Shin Chon Dong, \\ Suh Dae Moon Ku, Seoul 120-752, Korea \\ 2 Department of Surgery, Ajou University, School of Medicine, \\ Sweon, Kyung-Ki Do 442-749, Korea \\ 3 Corresponding author \\ Accepted 30 July 1997
}

Abbreviations: AP, apurinic or apyrimidinic; APE, AP DNA endonuclease

\begin{abstract}
Structural and functional changes in the major apurinic/ apyrimidinic DNA endonuclease (APEX) gene in human colorectal cancers were investigated. DNAs were prepared from surgically removed 25 human colorectal tissues and direct sequencing of PCR-amplified APEX gene covering the entire protein coding region was performed. Point mutations in 3 and silent mutations in 3 out of 25 colorectal cancer patients were found. Base substitutions in intron II were also found in 2 patients. $\mathbf{T} \leftrightarrow \mathrm{C}$ or some $\mathbf{A} \leftrightarrow \mathrm{G}$ transitions were the most typical pattern of the mutations. AP DNA endonuclease (APE) activities in normal and tumor tissues were $65.7 \mathrm{EU} / \mathrm{mg}$ and $21.7 \mathrm{EU} / \mathrm{mg}$, respectively. APEX protein was detected in both normal and tumor tissues and no remarkable difference in the amount of APEX protein between colorectal cancer tissues and their normal counterparts was observed. The incidence of APEX gene mutation in colorectal cancer was $12 \%$ which is relatively lower than that of other genes associated with colorectal tumor, but a significant reduction of APE enzyme activities in tumor tissues, especially in those with APEX mutations, was observed. These results indicate that the decreased APE enzyme activity might be closely related to the colorectal tumorigenesis, although no quantitative correlation between APE enzyme activity and APEX content exists.
\end{abstract}

Keywords: mutations, APEX gene, APE activity, colorectal cancer.

\section{Introduction}

Cells have evolved a number of mechanisms to ensure the high fidelity transmission of genetic material from one generation to the next generation since muations will lead to genotypes that may be deliterious to the cell. Lesions of DNA can lead to mutations and multiple enzymatic pathways for the repair of these lesions are known (Friedberg, 1990). Recent advances in understanding the genetic basis of malignant diseases have been achieved by researches in colorectal cancer. The cloning and identification of a number of genes involved in colorectal cancer development and susceptibility have been accomplished. $A P C, h M S H 2, h M L H 1, p 53$ and ras genes have been considered to be important involved in colorectal cancer. Mutations in $h M S H 2, h M L H 1$ and human homologue of E. coli mut $H L$ which are responsible to mismatch repair of DNA are known to be associated with hereditary non polyposis colon cancer (Fishel et al., 1993; Han et al., 1995). Apurinic or apyrimidinic (AP) lesions in DNA may be generated from spontaneous depurination (Lihdahl and Nyberg, 1972) or from the cleavage of glycosidic bond between various modified bases and deoxyribose unit of DNA (Lindahl, 1979).

AP DNA endonuclease (EC 3. 1. 25. 2; APE) recognizing AP site of DNA and nicking the DNA strand near the AP site, has been shown to be present in most cells, prokaryotes and eukaryotes (Brent, 1976; Thibodeau and Verly, 1980). Five classes of APE in E. coli have been reported (Friedberg, 1985) and more than two kinds of the enzyme were shown to be present in human or animal tissues (Ljungquist, 1977; Mosbaugh and Lin, 1980; Kim and Oh, 1990). The major human AP DNA endonuclease (APEX) which has APE, 3'-5'-exonuclease, DNA 3'diesterase and DNA 3'-phosphatase activities has been purified from human leukocytes and its CDNA has been cloned (Robson et al., 1991; Seki et al., 1991). Cloning and sequence analysis of genomic DNA of APEX has been reported (Harrison et al., 1992; Akiyama et al., 1994). Since little is known about APE in human colorectal cancer, we have analyzed the sequence of $A P E X$ gene in human colorectal cancer tissues in order to find any possible relationship between APEX gene and colorectal cancer.

\section{Materials and Methods}

\section{Preparation of DNA}

High molecular weight chromosomal DNA was prepared from 25 colorectal cancer tissues and some of their non- 
cancerous counterparts. Surgically removed fresh colorectal tissues $(0.5 \mathrm{~g})$ were homogenized with TES buffer (10 mM Tris, 25 mM EDTA, $0.5 \mathrm{mM} \mathrm{NaCl}, \mathrm{pH} 7.4)$ by OMNI tissue homogenizer (OMNI internationals, Waterbury, CT, USA), and nuclear fractions were sedimented by centrifugation $(600 \mathrm{~g}, 10 \mathrm{~min})$. Proteins in nuclear fraction were digested with proteinase $\mathrm{K}(1 \mathrm{mg} / \mathrm{ml})$ dissolved in $1 \%$ SDS and DNA was isolated by phenol-chloroform extraction according to the method of Davis et al. (1994). The purified DNA was dissolved in TE buffer $(10 \mathrm{mM}$ Tris-Cl, $\mathrm{pH} 7.4,0.1 \mathrm{mM}$ EDTA) and was used as template DNA for PCR amplification of APEX.

AP DNA (substrate for APE enzyme assay) was prepared from ${ }^{3} \mathrm{H}$-labeled $E$. coli chromosomal DNA by the method described by Kim and Oh (1993). The number average size (molecula weight, $\mathrm{M}_{\mathrm{r}}$ ) of AP DNA prepared in this preparation was $4.6 \mathrm{~kb}\left(3.036 \times 10^{6} \mathrm{Da}\right)$ and contained 12 AP sites per molecule of DNA when calculated from equation of Zubroff and Sarma (1976); number of AP site/ molecule $=\left[\mathrm{M}_{\mathrm{r}}\right.$ of control AP DNA/M $\mathrm{M}$ of AP site excised AP DNA]-1; where $\mathrm{Mn}=\Sigma \mathrm{Wi}(\Sigma \mathrm{Wi} / \mathrm{Mi})$; Wi=Weight of DNA in each fraction and $\mathrm{Mi}=$ Molecular weight of DNA in each fraction migrated upon agarose gel electrophoresis.

\section{Amplification and sequencing of APEX gene}

For the amplification of entire protein coding regions of APEX oligodeoxyribonucleotide primers (Figure 1) were designed and synthesized by ordering to Bioneer Co., Seoul, Korea. DNA segments corresponding to exon II through exon $\mathrm{V}$ of $A P E X$ were amplified by PCR according to the method of Saiki (1988) using each primer set and template DNA, and the amplified DNAs were purified by agarose gel (1\%) electrophoresis followed by the isolation of them using Gene Clean II kit (BIO 101, La Jolla, CA, USA). DNA sequencing reaction was performed by direct thermal cyclic sequencing method using amplicycle sequencing kit (Perkin Elmer, Branchburg, NJ, USA). The sequencing reaction products were subjected to SDS polyacrylamide sequencing gel $(8 \%)$ electrophoresis, and autoradiography of the dried gel was carried out to identify the nucleotide sequence of $A P E X$ gene.

\section{Enzyme assay}

APE enzyme activity in colorectal cancer tissues and their counterparts were determined as described by Thibodeau et al. (1980). Fresh tissues dissolved in TES buffer $(1 \mathrm{~g} / \mathrm{ml})$ were homogenized with glass homogenizer and nuclear fraction was sedimented by centrifugation (600 g, $10 \mathrm{~min}$ ). APE in the nuclear fraction was extracted with $1 \mathrm{M} \mathrm{KCl}$ in TES buffer for 2 hours at $4^{\circ} \mathrm{C}$. The extracted APE was centrifuged at $12,000 \mathrm{~g}$ for $10 \mathrm{~min}$, and the supernatant was dialyzed against TES buffer overnight at $4^{\circ} \mathrm{C}$. Protein contents in the dialyzed samples were determined by Bradford method (Bradford, 1976) and they were used for enzyme assay. Enzyme assay was performed according to the method described by Kim and Oh (1993). In brief, the reaction mixture of $100 \mu$ of $0.1 \mathrm{M}$ Tris- $\mathrm{HCl}$ buffer $(\mathrm{pH}$ 8.0) containing [ $\left.{ }^{3} \mathrm{H}\right] \mathrm{AP}$ DNA and $100 \mu \mathrm{l}$ of enzyme solution was incubated for $15 \mathrm{~min}$ at $37^{\circ} \mathrm{C}$. The reaction was terminated by addition of $100 \mu$ of ice-cold $2 \mathrm{mg} / \mathrm{ml}$ bovine serum albumin solution followed by addition of $60 \mu$ of $30 \%$ perchloric acid. The mixture was stand for $15 \mathrm{~min}$ at $0^{\circ} \mathrm{C}$ and centrifuged for $15 \mathrm{~min}$ at $12,000 \mathrm{~g}$. The supernatant $(100 \mu \mathrm{l})$ was removed carefully and radioactivity in it was counted by liquid scintillation counter (Packard, Downers Grove, IL, USA). The radioactivity in the supernatant after alkaline treatment of $\left[{ }^{3} \mathrm{H}\right] \mathrm{AP}$ DNA was assumed to be $100 \%$ AP site excised, and the relative radioactivity in the supernatant obtained from the enzyme reaction was used for the calculation of enzyme activity. Enzyme unit was defined as pmol of substrate (AP site) excised per min.

\section{Western blot immunodetection}

APEX protein expressed in the colorectal tissues was detected by Western blot immunodetection by the method described by Burnette (1981). A portion of APE protein prepared for the enzyme assay was subjected to SDSpolyacrylamide gel (12\%) according to the method of Laemmli (1970), and proteins in the gel were electrotransfered onto the nitrocellulose membrane. APEX protein on the membrane was immunodetected using polyclonal anti-APEX rabbit antiserum (kindly supplied by Dr. S. Mitra, University of Texas, Galveston, TX, USA) as primary antibody and peroxidase-conjugated anti-rabbit IgG antibody as secondary antibody. Peroxidase positive

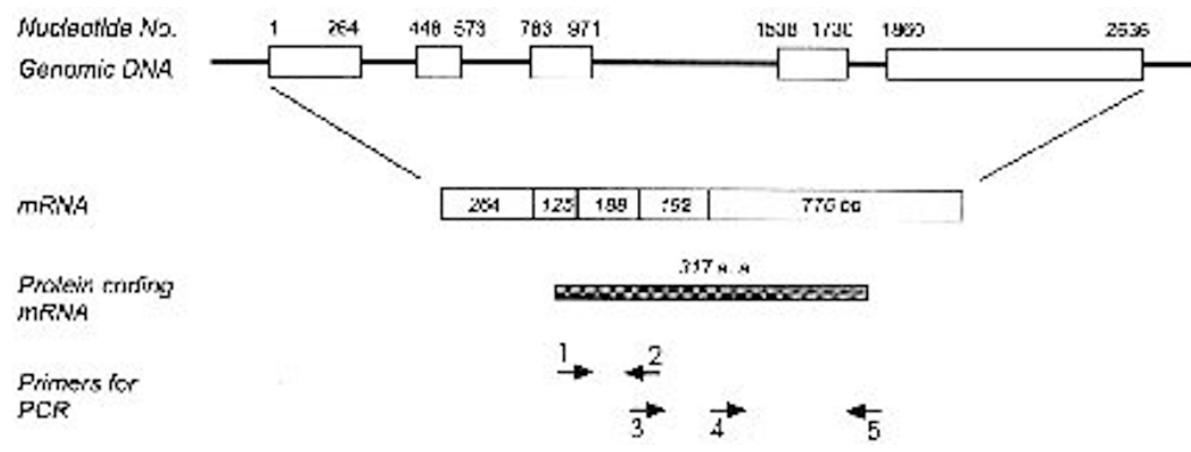

Figure 1. Schematic representation of APEX gene and the design of primers for the PCRamplification of exon sequences. The corresponding primer sequences are as follows. 1, Sense (exon II), 5'CGTTCGTAACGGGAATG-3'; 2, antisense (exon III), 5'-TCAAATTC CACTC-3'; 3, sense (exon IV), 5'-TACA GTGGGTAAAGGAAGAA-3'; 4, sense (exon V), 5'-GTG GATCCGAGGAGGAG CATGAT-3'; 5 , antisense (exon V), 5'GACTCGAGTCACAGTGCTAGGT-3'. 
signals were detected by ECL Western blotting protocol (Amersham, Buckinghamshire, England).

\section{Results}

\section{Mutations of APEX gene in colorectal cancer tissues}

Point mutations in the exon of APEX gene were found in 3 out of 25 colorectal cancer patients (Table 1, Figure 2). Leucine (CTT) at codon 108 of APEX gene was mutated to arginine (CGT) in one patient (No. 1), and serine (TCG) at codon 164 of APEX gene was also mutated to proline (CCG) in another patient (No. 3). Point mutations at 2 codons, GGC (No. 41, glycine) to AGC (serine) and CCT (No. 59, proline) to TCT (serine) were found in one patients (No. 11). Silent mutations at codon 293 (CCT $\rightarrow$ CCC), at $58($ AAT $\rightarrow$ AAG) and at $206($ GTG $\rightarrow$ GTA $)$ in three patients were found (Table 1, Figure 3 ). Base substitutions at nucleotide +587 and at +680 in intron II of APEX gene were found in two patients (Table 1, Figure 3).

\section{APE enzyme activities in colorectal cancer}

\section{tissues}

APE enzyme activities in colorectal tumor tissues were significantly lower than that of the normal counterparts (Table 2, Figure 4). The mean specific activities of APE in normal and tumor tissues were $65.7 \pm 26.7$ and $21.7 \pm$ 12.8 EU/mg protein, respectively. APE enzyme activities in tumor tissues which had point mutations in APEX gene $(17.7,10.3,6.3 \mathrm{EU} / \mathrm{mg}$ protein) were far lower than the average APE enzyme activity in all tumor tissues (Figure 4).

\section{APEX proteins in colorectal cancer tissues}

APEX protein was detected in colorectal cancer tissues as well as in their normal counterparts, and there was no remarkable difference in the intensity of APEX between tumor and normal tissues (Figure 5). APEX protein was also detected in the colorectal tumor tissues that have point mutations in APEX gene with a similar intensity.

\section{Discussion}

In recent years the cloning and identification of a number

Table 1. Mutations of the major human AP DNA endonuclease (APEX) gene in colorectal cancer patients

\begin{tabular}{cccccc}
\hline Patient & Codon & Point mutation & Codon & Silent Mutation & Intron II \\
\hline 1 & 108 & CTT (Leu) $\rightarrow$ CGT (Arg) & 293 & CCT (Pro) $\rightarrow$ CCC (Pro) & \\
3 & 164 & TCG (Ser) $\rightarrow$ CCG (Pro) & & & \\
5 & & & 58 & AAT (Lys) $\rightarrow$ AAG (Lys) & A $\rightarrow$ G $^{a}$ \\
6 & & & & & T $\rightarrow$ C $^{b}$ \\
8 & & & GTG (Val) $\rightarrow$ GTA (Val) & \\
11 & 41 & GGC (Gly) $\rightarrow$ AGC (Ser) & & & \\
& 59 & CCT (Pro) $\rightarrow$ TCT (Ser) & & & \\
\hline
\end{tabular}

a Nucleotide No. +587

${ }^{\mathrm{b}}$ Nucleotide No. +680

Nucleotide No. +1 represents the first nucleotide at the transcription initiation site.

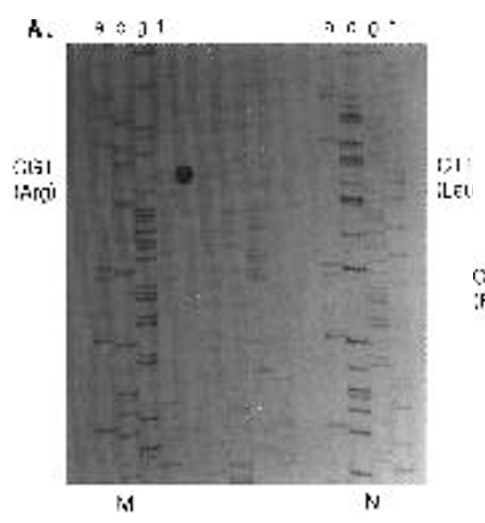

B.

Figure 2. Point mutations in APEX gene in colorectal cancer patients. A (patient No. 1): Point mutation at codon $108(\mathrm{~T} \rightarrow \mathrm{G}, \mathbf{O})$; B (patient No.3), Point mutation at codon 164
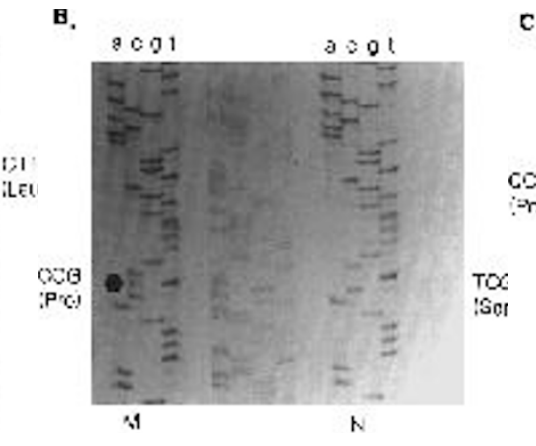

c. : $\leftarrow:$ : 1 a

$(\mathrm{T} \rightarrow \mathrm{C}$ $\mathrm{M}$ (mutant) are indicated.

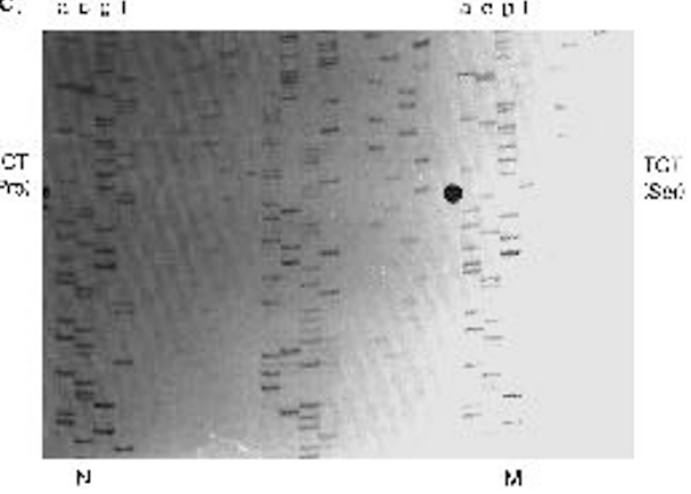

$\rightarrow \mathrm{T}$ ; (normal) and 


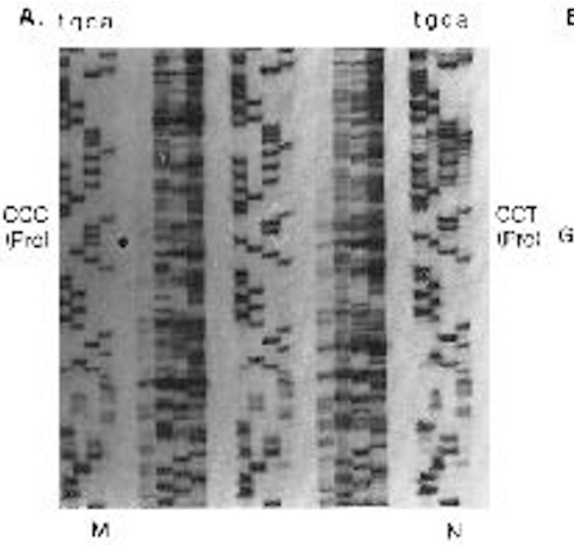

Table 2. AP DNA endonuclease activities in human colorectal tumor tissues. AP DNA endonuclease was prepared from surgically removed colorectal tissues by $1 \mathrm{M} \mathrm{KCl}$ extraction followed by dialysis overnight against a buffer (10 mM Tris- $\mathrm{HCl}, \mathrm{pH} 7.0$ ) according to the method described in the text. EU is defined as the amount of AP site (pmol) hydrolyzed for $15 \mathrm{~min}$.

\begin{tabular}{lcl}
\hline \multicolumn{1}{c}{ Group } & No. subjects & APE activity $(\mathrm{EU} / \mathrm{mg})$ \\
\hline Normal tissue & 4 & $65.7 \pm 26.7$ \\
Tumor tissue & 25 & $21.7 \pm 12.8$ \\
\hline
\end{tabular}

of genes involved in colorectal cancer development, and mutations in adenomatous polyposis coli $(A P C)$ gene, human homologue to the bacterial Mut LHS mismatchrepair gene, and human homologue to yeast genes involved in mismatch repair, PMS1, MLH1 or MSH2 have been reported (Miyoshi et al., 1992; Powell et al., 1992; Fishel et al., 1993; Cunningham and Dunlop, 1994).

An increased sensitivity of APE to genotoxic compounds such as $\mathrm{H}_{2} \mathrm{O}_{2}$ or alkylating agents in rat glioma cells has been suggested (Ono et al., 1994), but no evidences that the APE gene is related to colorectal cancer have been documented yet.

In the present study, the incidence of point mutation in APEX was about $12 \%$ (3 out of 25 ) which is somehow very low as compared to the incidence of point mutations in K-ras (40-60\%) and p53 (75-80\%) genes in colorectal cancer (Wiggers et al., 1988; Ponz et al., 1992; Levin et al., 1991). This result indicates that mutations in APEX gene may not have a significant role in colorectal carcinogenesis. However the reduced APE enzyme activity in colorectal cancer tissue of APEX mutant implicates that mutation of $A P E X$ gene may cause the defect in AP DNA repair function which may eventually lead to instability of many genes including oncogenes and antioncogenes.

APE enzyme activity in colorectal cancer tissues was significantly lower than that of their normal counterparts in this study, indicating that the enzyme activity is essential

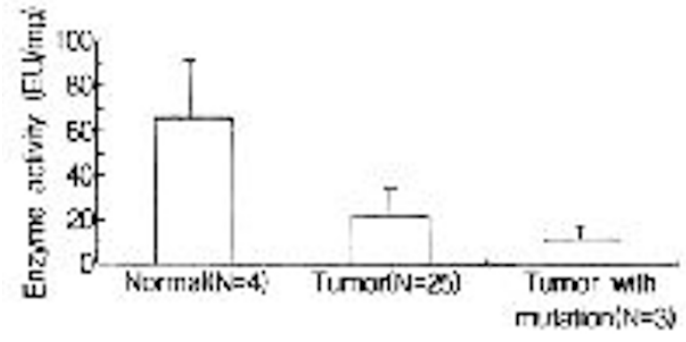

Figure 4. AP DNA endonuclease activities in human colorectal cancer tissues and their normal counterparts. $\mathrm{N}$ represents the number of patients and bars indicate standard deviations.
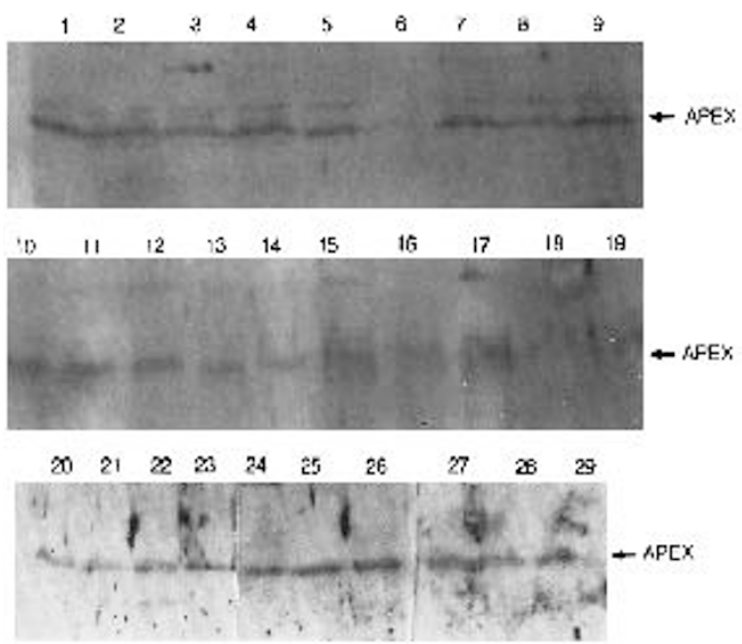

Figure 5. Western blot immunodetection of APEX protein in human colorectal tumor tissues. Tissues ( $300 \mathrm{mg}$ each) were homogenized in $300 \mu \mathrm{l}$ of solubilizing solution ( $150 \mathrm{mM} \mathrm{NaCl}, 1 \% \mathrm{NP}-40,0.5 \%$ deoxycholic acid, $0.1 \%$ SDS, $50 \mathrm{mM}$ Tris- $\mathrm{HCl}, \mathrm{pH} 7.5$ ) with Polytron tissue homogenizer and centrifuged for $10 \mathrm{~min}$ at $12,000 \mathrm{rpm}$. Portions of supernatants were subjected to SDS polyacrylamide gel electrophoresis. Proteins were electrotransfered onto nitrocellulose membrane and immunodetected using anti-APEX antiserum according to ECL detection protocol. Lane 1-4, normal counterpart of colorectal tumor tissues. Lane 5-29, Tumor tissues. 
for the maintenance of normal cellular functions which may be generated from healthy genes. APE enzyme activity measured in the present study represents the sum of all types of APE enzyme and the proportions of APEX gene product in the colorectal tissues is not known. So other types of APE gene products in addition to APEX should be encountered in the evaluation of the role of APE in colorectal cancer generation. Mutations in other types of $A P E$ gene have not been analyzed in the present study and the incidence of mutations in oncogenes or antioncogenes in the mutants of APEX have not been determined.

In a colorectal tumorigenesis model by Vogelstein (Vogelstein, 1988; Fearon and Vogelstein, 1990), multiple genes were thought to be involved in various steps of tumorigenesis; mutations in $A P C$ or $M C C$ in the early step, $K$-ras at the intermediate step and $p 53$ or DCC genes in the late step. Therefore the study on the change of APE activity in various steps of tumorigenesis will help the understanding how the reduced APE activity affect on the colorectal tumorigenesis.

A similar quantities of APEX protein expressed in the colorectal cancer tissues and their normal counterparts in spite of a significant difference in the APE enzyme activity between them indicate that APEX protein might not contribute much to the total APE activity present. But the reduced APE enzyme activity in the mutants of $A P E X$ gene implicates that biological activity of the mutant $A P E X$ gene products is extremely low.

\section{Acknowledgements}

This study was supported by Research Fund (1995-1996) of Yonsei Cancer Research Institute, Yonsei UniversityCollege of Medicine. We thank to Dr. Jin-Sup Choi for his kind supply of tissue samples.

\section{References}

Akiyama, K., Seki, S., Oshida, T. and Yoshida, M. C. (1994) Structure, promoter analysis and chromosomal assignment of the human APEX gene. Biochim. Biophys. Acta 1219: 15-25

Brdford, M. M. (1976) A rapid and sensitive method for the quantitation of microgram quantities of protein utilizing the principle of protein-dye binding. Anal. Biochem. 72: 248-254

Brent, T. P. (1976) Purification and characterization of human endonu-clease specific for damaged DNA. Biochim. Biophys. Acta 454: 172-183

Burnette, W. N. (1981) Western blotting: Electrophoretic transfer of proteins from sodium dodecylsulfate polyacrylamide gels to unmodified nitrocellulose membrane and radiographic detection with antibody and radioiodinated protein A. Anal. Biochem. 112: 195-203

Davis, L. G., Dibner, M. D. and Battery, J. F. (1994) DNA preparation from cultured cells and tissue. In Basic Methods in Molecular Biology (Davis, L. G., Dibner, M. D., Battery, J. F. ed.), 2nd Edn., pp. 305-314, Appleton and Lange, New York

Fearon, E. R. and Vogelstein, B. (1990) A genetic model for colorectal tumorigenesis.
Cell 61: 759-767

Friedberg, E. C. (1985) Excision repair 1 DNA glycosylase dna AP endo-nucleases. In DNA Repair, (Friedberg, E. C. ed.), p. 41, W. H. Freeman and Co., New York

Friedberg, E. C. (1990) The enzymology of DNA repair. Mutat. Res. 236: 145-314

Fishel, R., Lescoe, M. K., Rao, M. R., Copeland, N. G., Jenkins, N. A., Garber, J., Kane, M. and Kolodner, R. (1993) The human mutator gene homolog HSH2 and its association with hereditary nonpolyposis colon cancer. Cell 75: 1027-1038

Han, H. J., Maruyama, M., Baba, S., Park, J. K. and Nakamura, Y. (1995) Genomic structure of human mismatch repair gene, $h M L H 1$, and its mutation analysis in patients with hereditary nonpolyposis colorectal cancer (HNPCC). Human Mol. Genet 4: 237-242

Harrison, L., Ascione, A. G., Menniger, J. C., Ward, D. C. and Demple, B. (1992) Cloning of a major human AP DNA endonuclease gene. Human Mol. Genet. 1: 677-680

Kim, Y. S. and Oh, S. H. (1993) Purification and some properties of apurinic/ apyrimidinic DNA endonucleases in rat liver. Int. J. Biochem. 25: 1925-1933

Kolodner, R. D. (1995) Mismatch repair: mechanisms and relationship to cancer susceptibility. TIBS 20: 397-401

Laemmli, U. K. (1970) Cleavage of structural proteins during the assembly of the head of bacteriophage T4. Nature 227: 680-685

Levin, A. J., Momand, J. and Finlay, C. A. (1991) The p53 tumor suppressor gene. Nature 351: 453-460

Lindahl, T. (1979) DNA glycosylases, endonucleases for apurinic/apyri-midinic sites, and base excision-repair. Prog. Nucleic Acid Res. Mol. Biol.22: 135-192

Lindahl, T. and Nyberg, B. (1972) Rate of depurination of native deoxy-ribonucleic acid. Biochemistry 11: 3610-3618

Ljungquist, S. (1977) A new endonuclease from Escherichia coli acting at apurinic sites in DNA. J. Biol. Chem. 252: 2808-2814

Miyoshi, Y., Nagase, H., Ando, H., Horii, A., Ichii, S., Nakatsuru, S., Aoki, T., Miki, Y., Mori, T. and Nakamura, Y. (1992) Somatic mutations in the APC gene in colorectal tumors: mutation cluster region in the APC gene. Human Mol. Genet. 1: 229-233

Mosbaugh, D. W. and Linn, S. (1980) Further characterization of human fibroblast apurinic/apyrimidinic DNA endonuclease. J. Biol. Chem. 255: 11743-11752

Ono, Y., Furata, T., Ohmoto, T., Akiyama, K. and Seki, S. (1994) Stable expression in rat glioma cells of sense and antisense nucleic acids to a human multifuctional DNA repair enzyme, APEX nuclease. Mutat. Res. 315: 55-63

Ponz, M., Sant, M., Micheli, A., Bachetti, C., Di-Gregorio, C., Fante, R., Zanghieri, B. Melotti, G. and Gatta, G. (1992) Clinical phathologic prognostic indicators in colorectal cancer. Cancer 80: 626-635

Powell, S. M., Zilz, N., Beazer-Barklay, Y., Bryan, T. M., Hamilton, S. R., Thibodeau, S. N., Vogelstein, B. and Kinzler, K. W. (1992) APC mutations occur early during colorectal tunorigenesis. Nature 359: 235-237

Robson, C. N. and Hickson, I. D. (1991) Isolation of cDNA clones encoding a human apurinic/apyrimidinic endonuclease that corrects DNA repair and mutagenesis defects in E. coliXth (exonuclease III) mutants. Nucleic Acid Res. 20: 5519-5523

Saiki, P. K., Gelfand, D. H., Stoffel, S., Scharf, S. V., Higichi, R., Horm, G. T., Mullis, K. and Erlich, H. A. (1988) Primer directecd enzymatic ampli-fication of DNA with a thermostable DNA polymerase. Science 239: 487-491

Seki, S., Ikeda, S., Watanabe, S., Hatsushika, M., Tsutsui, K., Akiyama, K. and Zhang, B. (1991) A mouse DNA repair enzyme (APEX nuclease) having exonuclease and apurinic/apyrimidinic endonuclease activities: Purification and characterization. Biochim. Biophys. Acta 1079: 57-64

Wiggers, T., Arends, J. W., Schutte, B., Volovics, L. and Bosmam, F. T. (1988) A multivariate analysis of pathologic prognostic indicators in large bowel cancer. Cancer 61: 336-395

Thibodeau, L. and Verly, W. G. (1980) Cellular localization of the apurinic/ apyrimidinic 
endonuclease in rat liver. Eur. J. Biochem. 107: 555-563

Vogelstein, B., Fearon, E. R., Hamilton, S. R., Kern, S. E., Preisinger, A. C., Leppert,

M., Nakamura, Y., White, R., Smith, A. M. and Bos, J. L. (1988) Genetic alterations during colorectal tumor development. N. Engl. J. Med. 319: 525-532

Zubroff, J. and Sarma, D. S. R. (1976) A nonradioactive method for measuring DNA damage and its repair in proliferating tissues. Anal. Biochem. 70: 387-396 